\title{
Factors Influencing the Choice of Takaful Over Conventional Insurance: The Case of Malaysia
}

\author{
Naail Mohammed Kamil ${ }^{\mathrm{a}}$, Norsham Binti Mat Nor ${ }^{\mathrm{b}}$ \\ ${ }^{a}$ Faculty of Business, Accountancy and Management, SEGi University, Malaysia \\ ${ }^{b}$ International Centre for Continuing Education, International Islamic University Malaysia
}

\begin{abstract}
The present research attempts to study the factors that influence Malaysians to choose Takaful over conventional insurance. The study employs a qualitative research approach, conducting four intensive interviews with customers and Takaful Operators, who were selected from Klang Valley area in Malaysia. The respondents represent prominent Takaful Operators and their customers. The findings from the in-depth interviews led to the following major propositions; that Takaful customers have a clear concept of Takaful and the requirement of Shariah compliance; takaful is necessary for Muslims as a replacement of conventional insurance; takaful customers have awareness on the relationship between insurance and religion in contemporary business; the roles of Takaful agents in explaining the concept of Takaful and its benefits as acts of worship (Ibadah); the obligation by Takaful agents in promoting Takaful products to Muslims as acts of (dak'wah); and the growth of Takaful business remains slow compared to conventional insurance in the Klang valley area in Malaysia. Several implications of the research were further discussed.
\end{abstract}

(C) 2014 IIUM Institute of Islamic Banking and Finance.

Keywords: Takaful, Shariah Compliance, Takaful agent, Takaful Operators

\section{Introduction}

Takaful is an insurance product which is based on Shariah compliance. Takaful holds a different concept from conventional insurance which is rejected by the Shariah due to elements of uncertainty (gharar), interest (riba) and gambling (maysir). There is uncertainty of what the insurance policyholder is "buying" or paying for if no loss occurs where policyholder receives nothing. If loss occurs, policyholders get compensation in varying amounts. The second element in conventional insurance is gambling (maysir) and the third, element of riba where insurance funds are commonly invested in interest - bearing securities. With reference to the above, Takaful is an alternative to conventional insurance which presents itself as a form of mutual help (taawun) in furthering good/virtue by helping others who are in need or in hardship.

Shariah basis of Takaful is mentioned in Quran (5:2), Surah al Maidah. Allah says "Help (ta'awun) one another in furthering virtue (birr) and God consciousness (taqwa) and do not help one another in furthering evil and enmity". In a hadith, the Prophet Muhammad (peace be upon him) says "tie the camel, then submit (tawakkal) to the will of God".

In Islamic Legal Maxim, if damage has occurred, efforts should be made to remove it. Takaful participants contribute to a Takaful fund based on the concept of mutual assistance. The contribution is done via reciprocal/mutual donation (tabarru') and does not represent a commercial "sale of coverage". Takaful entails a unilateral, charitable contract (tabarru') in contrast with the conventional insurance contract which is a bilateral exchange contract (mu'awadat). However, Gharar is tolerated in a charitable unilateral contract.

According to Hamid et.al. (2011), Islamic and conventional insurance are two different contracts. Islamic insurance which is known as Takaful is based on the concept of Takaful that is developed on three principles: 1) Mutual responsibility 2) Co-operation with each other 3) Protecting one another from any 
kind of difficulties, disasters and other misfortune whereby the financial contribution (premium) is based on the concept of tabarru'.

According to Billah (2001), the word Takaful is derived from the Arabic word "kafala" which means to guarantee, look after or trust. Tabarru' is derived from the Arabic noun that means donation, gift or contribution. In relation to this, a participant agrees to contribute as tabarru', undertakes to pay, thus, enable him to fulfil his obligation of mutual help and joint guarantee should any of his fellow participants suffer a defined loss.

It is generally accepted by Muslim jurists that the operation of conventional insurance does not conform to the rules and requirements of the Shariah whereby conventional insurance involves elements of uncertainty (Gharar) in the contract of insurance, gambling (Maysir) as the consequence of the presence of uncertainty and interest (Riba) in the investment activities of the conventional insurance companies which contravene the rules of the Shariah (Hamid et al., 2011).

Even though Takaful business started in 1984 in Malaysia, the percentage of Malaysians buying Takaful products is quite low compared with the conventional insurance. Many promotions of Takaful products via the electronic media just started in recent years. Takaful Operators still have a slow pacing in getting to growth compared with their conventional insurance counterpart. Hence, Takaful Operators should determine factors that influence choice of Takaful products among Malaysians.

It is imperative to know the reasons Malaysian consumers engage in buying Takaful products. In other words, what are the factors that influence Malaysians in choosing the Takaful products? The present study investigates these factors based on independent variables such as knowledge of religiosity, perception, product features, promotion to customers, product benefits, quality of services provided by Takaful operators. Indirectly, the findings of the current study could help Takaful operators in improving quality of their products and services, so as to attract more people to buy their products.

The present study is guided by the following research questions; (1)what is the understanding of Malaysian consumers towards the concept of Takaful? (2) What are the factors that influence the choice of Takaful over conventional insurance among Malaysians? (3) How do customers receive information about Takaful products and its benefits; and (4) what are the customers' perspectives on Takaful's future in Malaysia? And (5) what are the level of customers' knowledge on the relationship between buying Takaful and religion?

In the attempt to find solutions to these research questions, the study is organized in the following sections; section one captures the literature review; section two highlights the qualitative research approach consisting of in-depth interviews with experienced and prominent professionals in the market; section three captures the analysis of findings; last but not least, section four highlights the conclusion and recommendations of the study.

\section{Literature Review}

This literature review explores the wide dominant judgment based on research works that were conducted to explore the factors contributing to the acceptance of the Takaful Products, dissimilarities between conventional and Islamic Products, efficiency, consumer behaviour and perceptions, market demands, marketing channels, financial strengths, and also the significant risks that impact Takaful Products.

A study conducted by Zainuddin and Noh (2013) highlights the overview of the emergence of Takaful as part of the Islamic type of policy. Their study attempted to gain a fundamental understanding of what Takaful is all about and how it varies from conventional insurance. In addition, they also aimed at boosting the level of understanding and bridge the gap caused by misinterpretation on the concepts and applications of Takaful as an insurance policy. The study concluded that Muslims are strictly prohibited in purchasing conventional insurance products as it is forbidden "haram" and violates the Islamic principles. Similarly, Abduh et.al. (2012) measured the performance and efficiency levels of the insurance industry in Malaysia between 2008 to 2010, highlighting both the conventional insurance and takaful. Employing ratio analysis and data envelopment analysis, the authors concluded that the insurance industry in Malaysia is more efficient than the takaful industry even though the difference in the efficiency levels in both industries is quite small. 
Meanwhile, a study by Billah (2000) highlighted numerous sources that could form the basis of law governing Islamic insurance. These include the primary sources which are holy Qur'an and Sunnah, and also the secondary sources including Ijma, Ijtihad, maslahah mursalah, urf, precedence etc. In addition, it was also indicated that the insurance policy remains valid if it is aligned with the Shari'ah principles.

In his other study, Billah (2002) compared the conventional system of life insurance and the Islamic model, owing to several arguments raised by the scenario of life insurance policy practiced under the conventional system. He reported that both conventional and Islamic designs tend to have different models and hoped that future applications of the Islamic life insurance policy would be successful. This finding also was supported by the study carried out by Hussain and Pasha (2011).

Qureshi (2011) in his works highlighted the residuals of conventional insurance that was still present in Shariah-compliant insurance either by compulsion or as a doctrine of necessity. It was found that two aspects of insurances were presented which were derived from reinsurance and investment of insurance funds. From the given background, it was concluded that though the concept of Shariah insurance has developed, still in these two areas the insurers were facing difficulties in meeting the requirements of the Shariah.

Per comparison between the acceptance of Takaful internationally and in Malaysia, Masud (2011) in her study, explored the underpinnings of the modern Islamic financial system and its impact to Takaful products, the foundation and the forms of Takaful and lastly the correlation of Takaful as applied in Malaysia with the potential for a Takaful market in the USA. The researcher captured that it was quite trivial to implement the Takaful market in the USA due to no difference in statutory authorized regulatory framework between the Islamic and conventional. Another related contention has been studied by Ahmad et.al. (2010) which analyzed the reputation of Takaful in the insurance sector worldwide throughout all the possible aspects in terms of the insurance system. The study reported that the customer knowledge related to the Takaful is still considered shallow due to minimal understanding on the Islamic finance in the banking and insurance sector.

In addition to this, the marketing of Islamic financial products played significant roles in driving the Islamic way of banking and insurance in the entire universe. For instance, a study that relates to the knowledge of customers regarding Takaful was conducted in Brunei by Matsawali, Abdullah, Ping, Abidin, Zaini and Ali (2012). Matsawali et al. (2012) performed random sample basis and probed the public preferences and understanding between Takaful and conventional, and the particular aspects where conventional insurance contradicts Shariah principles. The researchers reported that even though the public preferred Takaful products over conventional insurance, the level of knowledge by the majority in the public is still very minimal.

In terms of the awareness and knowledge of Takaful among Malaysians, Ayinde (2012) captured that Malaysians are willing to adopt Islamic insurance services depending on significant factors including compatibility and awareness. A similar study by Swartz and Coetzer (2010) also concluded that Takaful products have attracted even non-Muslim communities. Nonetheless, the interest shown by non-Muslims and the support of Muslims is insufficient to promote the knowledge and awareness to lead the growth of Takaful. These contentions made by the researchers seem to suggest that lack of knowledge and awareness are among the greatest challenges to the development and growth of the national and global Takaful industry.

A study conducted by Razak et.al. (2013) have explored the factors that influence the acceptance of Takaful among Malaysians based on perception, product, features, promotion, benefit and service quality. The researchers reported that service quality was the most significant factor on why the Malaysians chose to purchase Takaful products. Again, a similar study conducted by Rahim and Amin (2011) focused on the relationship among attitude, subjective norm, and amount of takaful information obtained. The research captured that all three factors of attitude, subjective norm, and amount of takaful information obtained were part of the influential predictors of Islamic insurance acceptance.

In terms of the agents' impact on the Takaful Products, Hamid, and Rrahman (2011) researched on the relationship between commitment, motivation and attitudes with performance of the industry. It was found that those three significant variables have an impact towards the performance of the Takaful products in the insurance market. Another research by Hamid et.al. (2010) explored the relationship between theoretical determination factors and performance by the Takaful agents for human capital 
development. It was concluded that Takaful operators are in dire need of enthusiastic agents to act as representatives, thus, one of the main human capital development in Takaful.

On the other hand, Salleh and Kamaruddin (2011) investigated the effects of personality attributes by determining the sales performance of the Takaful's agents. Two out of three personalities (i.e. selfefficacy and self-monitoring) were found to be positively related to the sales performance; while locus of control was found to be inversely related to sales performance.

A quite similar study related to the agents and system efficiency has been carried out by Annuar (2004). The study was to ascertain the perception on the importance of the agents and to examine which marketing channels will be the most selected by the current and potential customers. The researcher reported that the most preferred marketing channel was the agency system (al-wakalah) due to the ability to generate greater benefits (manfa'at) to both parties.

There are quite a numbers of studies carried out in relation to family Takaful products. One of such studies is the work of Gustina and Abdullah (2012). The study investigated the factors that contributed to the demand in family Takaful compared with conventional counterpart. Four variables have shown significant impact in demand to the family Takaful including GDP per capita, Education, saving and religion compared to the conventional products; which only have three variables of significant impact (i.e. GDP per capita, saving and religion). Moreover, it was found that population of the Muslims, change in mindset and; benefits and pricing have impacted the influences of family Takaful products.

A similar research by Redzuan et.al. (2009) noted that income per capita was a robust predictor of family Takaful demand. Again, it was also shown that long-term interest rate and composite stock index have significant relationships with family Takaful consumption, and saving rates and inflation did not appear to be significantly influenced. In addition to that, the works of Sherif and Shaairi (2013) has demonstrated that factors such as income, Islamic banking development, education, dependency ratio and Muslim population are positively related to Takaful demand, while on the other hand, inflation, real interest rate, financial development and life expectancy appeared to be significant factors that adversely influence total family Takaful consumption.

However, Yazid et.al. (2012) found evidence to support the contention that the percentage of society covered by family Takaful contracts in Malaysia is still lower compared to conventional insurance. Yazid et al. (2012) further reported that socio demography and economic factors are the main determinants of family Takaful.

Furthermore, Siala (2012) investigated whether religiosity and religious centrism of Muslim consumers can instill attitudinal brand loyalty towards an insurer selling a religiously - conforming high-involvement indemnity service. The results of the research showed that there is a positive relationship between the exogenous religiosity and religious centrism constructs, and the endogenous attitudinal brand loyalty, price tolerance and word-of-mouth constructs.

The research by Ismail, Alhabshi and Bacha (2011) found that there was a significant difference in technical efficiency between Takaful industry and insurance industry. Ismail et al. (2011) discovered that takaful has lower technical efficiency than conventional insurance. Contrary to that, Saad (2012) examined the efficiency of general or non-life Takaful and insurance industry in Malaysia for the period of 2007 to 2009. It was concluded that Kurnia Insurance has the highest amount of output for both premium and net investment income. Whilst for input, it was shown that Kurnia and Prudential BSN Takaful Bhd were the top insurers who have biggest number of inputs, commission and management expenses, respectively.

In terms of financial strength, Yakob, Yusop, Radam, and Ismail (2012) studied CAMEL rating system for each of the conventional life insurers and Takaful operators. Yakob et al. (2012) reported that the financial stability of Takaful insurance operators were fundamentally sound. In addition to this, it was shown that CAMEL rating is a promising approach in providing an overview of the financial strength of the life Takaful insurance operators towards the benefit of policyholders.

In terms of the relationship between understanding of Takaful concepts related to the Takaful schemes, gender, profession and income, Awang and Zakaria, (2005) captured that there was no relationship between the understanding and the participation with the three variables of gender, profession and income. Nevertheless, there was a positive relationship between the understanding of Takaful and participation in Takaful schemes. A similar study by Salleh, Abdullah and Razali (2013) investigated takaful agents' understanding of the objective and concepts of takaful as well as the factors that contributed towards that 
understanding. Employing descriptive statistic and factor analyses, Salleh et al. (2013) reported that the understanding of takaful concepts among takaful agents was found to be discontented. Again, learning culture was found to be the most influential factor that impact agents' understanding of takaful concepts. The authors made some recommendations to the takaful industry to prepare an effective learning environment for their agents with regard to takaful concepts in order to strengthen their marketing efforts.

Furthermore, the works of Billah (2002) investigated how the contributions paid by the policyholder should be regarded, either as partial capital to a Mudharabah financial deal or as a total donation to a charitable fund, or should the contributions be paid into two accounts (i.e. partial amount would be regarded as a capital to a Mudharabah financing deal, while the remaining partial amount will be given away to the charitable fund of the company as a Tabarru' standing or donation). It was suggested that under Islamic law, there is no circumstance which may render a policy forfeited with paid-contributions even if the participant commits a breach of good faith or any other offences. This was due to the fact that an insurance policy is a financial transaction in which the paid-contributions are the lawful right of the participant, which cannot be forfeited just because of his evil acts.

Htay and Zaharin (2011) studied the motives behind the selection of different Takaful models which impacted the surplus distribution of Takaful funds, especially for family Takaful funds. The study proposed a model to be adopted by Takaful operators in order to be fair and equitable for both Takaful operators and participants. In generic view, the two most commonly used models in Malaysia are Mudharabah and Wakalah contracts. However, Takaful operators in Malaysia specifically prefer the use of the Modified Wakalah Model or Hybrid Wakalah Mudharabah model for managing their family Takaful business. The main reason was due to the Shariah issues inherent in the Mudharabah Model. The researchers reported that some of the respondents believe they have been unfairly treated by this model due to excessive profit taken by Takaful operators, whilst some others opined that this model is very excellent for starting a new family Takaful business.

A most similar study by Ghazali et.al. (2011) which examined and derived the most suitable formula for life tables comparing two models, Mudharabah and Wakalah which related to the Surrender Value, Maturity Value and Death Coverage. The research reported that clients would be better off if they had chosen a Takaful company that applies Mudharabah and Wakalah Models.

There are also quite a number of studies pertaining to the risk evaluation in Takaful. For instance Fisher and Taylor (2011) explored the growth of Takaful as a means to tackle risks and engage in longerterm financial transactions. The study provided the profile and statistics of global insurance industry along with the size and scope of Takaful markets worldwide. It was found that numerous Takaful schemes and re-Takaful (reinsurance) facilities have appeared in many countries as Islamic alternatives to conventional (re)insurance. The Takaful models were being categorized into three groups: non-profit, Mudharabah, and Wakalah. Hence, it has stressed that an overriding purpose of Takaful is cooperative risk which is sharing for community's wellbeing and not profit maximization.

Another study regarding risk was carried out by Aris et.al. (2012). The study investigated the risk of Takaful Company. It was concluded that as per alignment to the Shariah requirements and the concept of Takaful, risk management practice and management of a Takaful operators were to be better off than a conventional insurance operators. Moreover, protection in accordance to the Maqasid al-Shariah will tend to be integrated into the Islamic finance activities. Hence, Takaful operators suggested being proactive in managing their risks as part of good governance and best practice code.

Abdullah (2012) examined Takaful's growth towards an effective risk management and ethical promoting tool which tailored to the Maqasid of Shariah. The research captured that protection of human dignity was being prioritized to honor and treasure individuals without discrimination. It was also highlighted that Islamic virtuous goals and values that are highly thought of in Takaful are believed to pave the future direction to achieve the universal objectives of Shariah.

Lambak (2013) examined the act of applying gharar (risk) in predetermining Takaful contribution (premium) to offer a juristic opinion from Islamic Shariah perspective. It was found that gharar (risk) in principle is a subject that is recognized in Islam. It would then lead to main inference that making a gharar (risk) as a consideration in contribution calculation is permissible from Shariah perspective. Arifin, Yazid and Sulong (2013) proposed a simple yet comprehensive conceptual model to identify the main determinants that drive family Takaful demand in Malaysia. Arifin et al. (2013) mentioned that there are 
four important factors that could possibly influence family Takaful demand, i.e. the agency system (al wakalah), reputation and recommendation, product and services, marketing and advertising.

With reference to the above-captured literature, it can be noted that most researchers have aspects of Takaful operations in Malaysia and some of the daring challenges being faced by Takaful operators in general. Yet, there are still quite a number of factors which are less highlighted such as the salient reasons that influence Malaysians in general to tend to choose and prefer Takaful over conventional insurance. This is the gap for which this study attempts to discuss and make genuine contributions. Owing to the fact that the authors attempt to delineate in-depth factors for which Malaysians partake in Takaful activities, a qualitative research approach is adopted in this study. The next immediate section discusses the methodology employed in this study.

\section{Methodology}

The researcher has chosen to do a qualitative research as the method to answer the research objectives stated earlier. Qualitative research has helped the researchers to interpret and better understand the complex reality of the current reasons of the chosen the Takaful customers. The most suitable research technique for this is the qualitative method and this can be justified by the following reasons:

1. The study requires people's knowledge, understandings, views, interpretations, experiences and interactions. Thus, interviewing is the most meaningful and relevant instrument to the design research questions.

2. The study was intentionally made flexible in order to maximize the collection of intensive and high quality information for the success of the study. The interview guide was designed to encourage participants to contribute their own ideas and share their experiences with relevant information and by providing their own experiences, information or views on the relevant issues.

\subsection{Qualitative Research Method}

The in-depth interviews are considered to be the best to describe and understand respondents' views of the factors that influences the choice of Takaful products among Malaysian. This is in line with Schaltzman's and Strauss's (1973) assertion that the interview must be used to provide context and meaning. Their justification of the interview as a critical qualitative tool is pertinent to this study. For this study, a semi structured face to face interviews were done using an interview guide provided by Sekaran (2003) in which the topic and questions are notified in advanced before the actual interview sessions take place. The keenly nature and specificity of responses provided the substance of the descriptions that contributed to affective material for the factors influences choices of Malaysians buying Takaful products. The Takaful concept is increasingly understood and well accepted among Malaysians. Details, personals and stories told by the participants demonstrated the relationship of Takaful and religion ascribe to the concept of Takaful.

\subsection{Sample Design}

A sample of four customers of Takaful products was chosen for the study. Two of them are staff of prominent Takaful Operators who have been working for 7 years and 11 years respectively. The justification for these choices was to explore the meanings attributed to factors that influence the choice of Takaful products among Malaysians. Time and budget constraints did not allow for a large sample from various Takaful Operators in the country. While the aim of sampling in a survey or experimental study is to select a representative sample of population for generalization and prediction purposes, the aim of selecting of respondents in this exploratory study is to test new ideas and interpretations. Hence, as asserted by Cooper and Schindler (1998) the sample needs not to be representative of a larger population as in the case of survey or experimental studies.

The respondents from staff category of Takaful Operators consisted of one male and a female. One of them is a Manager of Syarikat Takaful Malaysia Berhad with and the other is an Assistant Manager of Takaful Ikhlas. Both of them are graduates and full-time employees with not less than 7 years of working experiences with Takaful companies. The two customers of Takaful products are females and both of them are working in private organization. 
Face to face interviews were conducted with respondents from Kuala Lumpur. All respondents were Muslims by faith, and thus, religious belief played an important role in the professional conduct. There was a general consensus among the respondents that as Muslims, it was obligatory upon them to observe the factors that influences the choice of Malaysians in buying Takaful products. Their insight towards buying takaful is part of a way of life to a Muslim and it is obligation to get protection of Takaful rather than conventional insurance. This could be found later in the results of data analysis section of this paper.

\subsection{Data Collection}

The data collected was interpreted using content analysis method. Open ended questions were used during the intensive interviews. The total duration of each interview was approximately 49 minutes without any break. Thus, the total amount of time spent for interview purposes amounted to approximately 3 hours. Semi-structured interview format was adopted in this study. The participants were encouraged to express their thoughts freely on issues pertaining to their beliefs, knowledge and practices. All the interviews were audio recorded (with permission) and then transcribed at the early stages of data collection. Notes were also taken during the interviews to capture informants' emotions such as nodding, laughter, smiles, frowns and other indicators which aided in the data analysis.

Firstly, the researcher listened several times to the recorded interview data. The pre-scheduled personal interviews were conducted at the offices of participants' preferred locations. The data was then reviewed and transcribed in a written form. At the same time, the data is organized by question to look across all respondents and their answers to identify commonalities and differences.

\subsection{Data Integration and Analysis}

The data collected through interviews were transcribed and then integrated. All the data acquired were examined and categorized recombining the evidence to address the research questions of this study. The identity of the research participants will remain confidential in line with ethical norms and considerations. A coding process was utilized for this purpose. For instance, the two categories of customers and staff of Takaful Operators were coded as $\mathrm{C}$ and $\mathrm{S}$ respectively. The individuals from these categories were coded as $\mathrm{C} 1, \mathrm{C} 2, \mathrm{~S} 1$ and $\mathrm{S} 2$. The coding process was utilized to ensure confidentiality of the names, positions and organizations of the research participants. Constant comparative analysis of data (Glaser \& Strauss, 1967) was conducted to generate themes as they relate to the informants' perceptions of understanding of Takaful and relationship with religious and its practices in their various organizations.

The structure of reporting the results of this exploratory study has been organized in context of the five key issues that are covered by the research questions. The main issues are: the concept of Takaful, the factors that influences choice of buying Takaful, knowledge of Takaful and its benefits, Takaful's future in Malaysia and the affiliation of buying Takaful and religion. The focus of the reporting structure was to explore the extent to which informants ascribe meaning to Takaful and the possibility this may serve as antecedent to Takaful. The results are presented categorically to match with the main purposes of this study.

\section{Concept of Takaful}

Although there were several concepts that the respondents ascribe to the concept Takaful, most the respondents agreed upon certain aspects of dimensions encompassing the concept of Takaful. All the four respondents highlighted the concept of Takaful as a contribution put in a pooling system accordance with Shariah law to help each other (tabarru') among participants in Takaful. Respondents have the following to say:

"Takaful is Islamic insurance where the members contribute money into a pooling system in order to guarantee each other against loss or damage. Takaful insurance is based on Shariah Islamic religious law and explain how it is the responsibility of individual to co-operate and protect each other....." (C1).

Similarly, another respondent said:

"The basic concept of Takaful is based on Shariah point of view. Mutual co-operation of mutual benefit, I mean to those who contribute to the Takaful fund. That's the best concept that we should 
appreciate because it's unlike conventional. Conventional, the fund belongs to insurance operator or company itself. But in Takaful concept we have "tabarru' the pull of fund whereby it belongs to contributor itself or participants. So, this is the best concept as a Muslim, this is a part of our "sedeqah". We consider it as "sedeqah" because we help each other for those who contributed. And of course when we understand Shariah, the three elements that make the conventional different from Islamic that the element of gharar, maisir and the riba shouldn't be in the Takaful. Something that we have to take it seriously that Takaful is Islamic...."(C2).

A similar meaning was given by respondent (S1) on the concept of Takaful:

"Well, Takaful meaning is you come together with mutual needs. What is mutual need? The mutual need is the protection. And then, this group of people, they contribute money with the terminology is "tabarruk". So, the purpose is this pool of fund will be used to cover each one of the member in the unfortunate event. Now what is the different, if you ask me between Takaful, and conventional insurance? First of all, there is what we call intention or "niat". Because for Takaful, it begin with "niat". Your "niat" is you come together. You set aside some money. So that, this money will help every one of the member who participate. Unlike conventional insurance, there is no element of "niat" but only the initial intention to buy protection." (S1)

Similarly, another respondent (S2) said:

"Takaful is the concept of co-operation, protection, responsibility and helping each other. Yes, it is tabarruk, we put our contribution is one pool to help each other..." (S2).

The preceding discussion leads us to the understanding of concept of Takaful that people who buy Takaful products have awareness on concept sedeqah and tabarru'. They have intention to avoid of gharar, maysir and riba which are prohibited in Islam.

\section{The Factors That Influences People To Buy Takaful Product}

There is a consensus in the views of the respondents regarding the factors that influence choice of Malaysian people buying Takaful products. Respondents are of the views that change from conventional insurance to Takaful is an obligation to avoid gharar, maysir and riba which are prohibited in Islam.

For instance, respondent (C1) mentioned that:

"One of the factors that encourages me to purchase a Takaful product is the agent. One of the staff of IT MAA has introduced me about Takaful. He is the one of the tops agents in BSN-Prudential Takaful right now..." $(C 1)$

Another respondent (C2) mentioned that:

"I think because of the awareness. Our awareness is actually the importance of Shariah compliance in our daily life as Muslims. As much as possible, we try to live to become a good Muslim. So, in everything we do, if we have better choice then we should go to this kind of product now. I know that, I studied also Islamic Finance, so I know that Islamic is something for Muslim, not for Muslim only but to Non-Muslim as well. But as a Muslim, we much need for this kind of product. So, we should support and use this. That's why in everything in every protection that I bought, if there is Takaful for it, than I will opt for Takaful products." (C2).

In similar way, another respondent (S1) had mentioned that:

"...For me, the most important thing is as a Muslim, I have a choice. Before this, always people said, "You don't have a choice. You only have conventional insurance that provide cover for your car and if you don't purchase the cover, your car cannot be driven on the road. But with Takaful, I have a choice between going to conventional and going to Takaful. So, I choose Takaful, "Islam is a way of life". Now, I'm happy to say that many Takaful products are becoming more innovative. More Takaful Operators are offering more choices even among family products. So, most of these players, they are providing Single 
Premium product and general product. So, with additional more Takaful Operators, we have so many Takaful products to choose. We should choose based on our needs.” (S1).

The respondent (S2) said:

"From my point of view, I want to change from conventional to the Islamic. I think, it is the obligation for Muslim to support Muslim product."

In addition to this, respondent (S2) also put forward a statement that:

"I think some of people know about concept of Takaful and they want to change from conventional. As I said, because Islam prohibited gharar, maisir and riba. They have own knowledge. So, they want to change from conventional. That is their initiative. May be they study...." (S2).

The foregoing discussions, thus, concludes the standpoint of Islam prohibited the elements of gharar, maisir and riba. These factors embedded in the conventional insurance are among the factors that influence respondents to migrate from conventional insurance to Takaful products. Respondents seem to unanimously agree that as Muslims they have the obligation of not only following the norms of what is commonly available in the market presently (i.e. conventional insurance scheme) but they also must support and make attempts to protect their religious duties, thus, safeguard their akhirat as well as their worldly living. This seems to suggest that, taking the obligation to find avenues to protect ones religious duties and life can be considered as acts of worship (Ibadah).

\section{Getting Knowledge of Takaful Benefits}

In terms of how the respondents get information of Takaful benefits, almost all the respondents echoed that agents of Takaful played important roles in promotion of the benefits of Takaful. They knew the benefits of Takaful through consultation given by Takaful agents who influence them to buy Takaful products.

Respondents have the following to say:

"...II also working at insurance company. So, talking about Takaful, before this I working at MNI. MNI got Takaful insurance. I know a little bit from Takaful MNI. I know from newspapers, and I know form friends. The benefits of my Takaful cover investment, medical, cover medical hospital benefits, cover critical illness and cover personal accident. I bought a policy which covers everything what I wanted. No need to buy many policies. One policy covers everything..." (C1).

Similarly the respondent (C2) said:

"..Basic concept of Takaful I think people might call it Islamic insurance protection basically may be not much different from conventional. Thus, it is important for us to take the initiative to understand Takaful products whether it's General Takaful or Family Takaful (referring to the conventional "Life" insurance)..Life Takaful. It's not much difference. But of course every company Takaful Operator has their own way of packaging their product. For that reason, we have preference, then, we should maybe google. Nowadays, Mr. Google is very famous. So, we should get more information through that. If we really have something in mind, something that you want to focus to. But if, I think the most effective one is when you access to any agent whereby agent can explain better about the product. We can question him/her as long as you want. We can just ask her. I think more effective in terms $f$ knowing the product and the benefits of the Takaful product."

Similarly the respondent (S1) said:

"Most of it I would say from reading the product specification and understanding the Takaful model adopted whether it's fully Mudharabah or is it Wakalah or is it modified Wakalah. As I mentioned just now, most of my employers are kind enough to send me to a lot of Takaful or Islamic financial training which also give me more knowledge in term of know your product. Furthermore, in my capacity now in doing operation, I need to know well the Takaful product because I'm dealing with collection of Takaful 
contribution from the public. Sometimes we receive complaint or inquiries from them and our agents. So we need to know the product well in order to give them the service that they require."

Similarly the respondent (S2) said:

"Because I studied in area of insurance, I learned about Takaful before but at that time we don't have lot of company so only Takaful Malaysia. Since I started working here, I learned more details about Takaful."

From the forgoing discussion, respondents seem to agree that they got knowledge of Takaful through reading or through internet and promotion given by Takaful agents. Promotion given by Takaful agents seems to run across all the respondents' views. This leads us to the belief that Takaful operators in general must ensure their Takaful agents are well educated regarding Takaful products both in theory and practice, as these agents are the foot soldiers and the points of reference for potential Takaful customers. This as well seems to suggest that the act of promoting Takaful products may be considered as acts of dak'wah.

\section{Future of Takaful Business in Malaysia}

Respondent have a same perception of the future of Takaful in Malaysia. Respondents generally were quite hopeful for a better and brighter future regarding the growth and development of Takaful in Malaysia. For instance, respondent $\mathrm{C} 1$ said:

"Ok. Takaful has a big future in Malaysia. Just most people in Malaysia is like to buy Muslim product based on the Shariah and Islamic Law. Then, Takaful also has support from government, Bank Islam and Tabung Haji. All the Malays are very religious and to buy Muslim product which is Islamic. So I think it is big future in Malaysia. So you can see, growth of the Takaful right now. Every insurance company has Takaful. See, Last time for example MAA Assurance now got MAA Takaful. ”(C1).

A similar view from Respondent C2 said:

"I think Takaful has a better, I mean, a bright future in Malaysia compare with conventional because Malaysia wants to become a financial hub for ASEAN countries, focusing on Islamic finance. So Takaful is part of it. That's why we can see lots of foreign company, foreign Takaful operator joining with our local company and open up and get the license from Bank Negara. If I'm not mistaken, it's more than 10 Takaful operators in Malaysia. But it's still under control in the sense Bank Negara will not issue new license without knowing who be the operator. Something like that. The numbers of it, they have to control this so that it become more competitive to the local itself. So to think Takaful will be a bigger one... (pause) not to say...:Yes. They can be as competitive as the counterpart or the conventional. They must be a better in terms of awareness. Malaysia has lots of Muslim. I think more than 50\% in Malaysia. So if the Muslims support, buy this Takaful product. It's not limited to Muslim, also for non-Muslim, if they understand the concept of Takaful itself, how it's different from conventional. So that's why the agents has to play major role to educate not only educate themselves (ringtone ring) they have to deliver it to the public on how to explain, how to improve their life using this Takaful product. So I think in Malaysia has a bright future but depends on the support of government and people especially. Like you. You have to start buying or convert to Takaful."

Respondent (S1) also mentioned the future of Takaful as:

"With the introduction of the IFSA, as I mention just now, the playground will be level. After the addition of new Takaful operators by Bank Negara for the past 5 to 10 years and with further liberalization we can see more foreign company taking up interest and stake in Takaful Company. For example, the latest if you know, Made Life of America owning 49\% of M Takaful and they also own 51\% of $M$ Insurance. You can expect more foreigners coming. You can see the playfield of insurers are becoming more vibrant for example, they are coming out withnew ideas, products, way of selling thing, way of operation, and way of running company. Furthermore, usually this player when they come to Malaysia to invest, they are not just looking at the conventional. They really want to Takaful. Once they 
success Takaful in Malaysia, they are looking other region in Southeast Asia like Indonesia for example, the biggest Islamic market in Southeast Asia.” (S1)

Respondent (S2) also mentioned the future of Takaful as:

"As I just said just now, other conventional is open their section for Takaful. So I think there could has been bright future for Takaful to growth in Malaysia. I think they know the concept of Takaful is good, people will buy our Takaful product."

The above discussion seems to conclude that Takaful has brighter future in Malaysia, owing to the fact that even the many conventional insurance companies in the country are also showing some interest in the Takaful operations. Takaful has attracted many foreign companies to invest in Takaful business in Malaysia. With the introduction of the IFSA, and the addition of new Takaful operators by Bank Negara for the past 5 to 10 years and with further liberalization, more foreign companies taking up interest and stake in Takaful company. Thus, more international companies are expected in Malaysia, thus, expanding the Takaful operations.

\section{The Relationship between Buying Takaful and Religion}

There was an undisputed agreement regarding the positive relationship between buying Takaful and religion. From their knowledge and experiences, respondents mentioned that they believe, that buying Takaful is obligation to Muslims because it is regarded as Shariah compliant, whereby it is free from elements of riba, gharar and maysir. Buying Takaful with intention of worshipping Allah would may attract a reward from Allah.

For instance, respondent (C1) mention that:

"As Muslims, you have to support the Muslim products because the Takaful product is based on the Shariah law. Where there is no elements of riba, al maisir and al gharar." (C1).

Likewise, respondent $(\mathrm{C} 2)$ clearly commented that there is a relationship between buying Takaful and religion where she said:

"Takaful and religion is very much close to each other. Why? Because in religion, in Islam (we're talking about Islam). So, I refer to Islam, not other religion. In Islam, we have this Makasid of Shari'ah. So, one of the objective in this Makasid is to protect your wealth. In that sense, we're buying Takaful not only for us but also for our generations. An example is when you're buying a Family Takaful product. Maybe you're protecting yourself for now so that not burden your family. In case of any emergency, you have to be hospitalized, you're well protected. Then, and anything happen to you, also, maybe your family you left behind will get some compensation. The most important thing in Takaful is helping each other, is a mutual corporation or benefit. Yes. Ta'awun. In that sense, is what our religion, in Islam that we have to help each other. So when we invested in tRespondent (S1) said Takaful product, we already made ahead that this payment will goes to who participated in that. The pool of fund can be used to help those people in difficulties. At the same time also, if we are in that situation, the unfortunate one, so the same thing will happen. The same pool of fund will be used to protect us, to compensate us. And then to the Tabarru' fund, if there any excess to it, it can be can be shared among the participants. It's something that other conventional not doing it. If you're familiar, for example, Takaful Ikhlas Malaysia, yearly you might get certain amount in return of our contribution and you have not claim during that year." $(C 2)$.

Similarly another respondent (S1) commented:

"As of Muslim, not only what you eat that must be halal. Before the Takaful exist in Malaysia in 1994, you no choice at all. You only have conventional only. For me, as a Muslim, we should support Takaful operators. Reasons being, number one - the more people participate, the more funds available to cover more people. Two, the more funds available, more things can be done. More innovative, more investment can be done. Three, with the available funds, you can influence others for example sukuk, Islamic shares, Islamic counter. Because, before this you don't have this alternative. Now, as a Muslim entity, if you want 
to invest your money, looking back to 20 years ago, does not many Islamic companies with qualify the share as Shari'ah compliance. It's help the all community. It's all part of the life. I believe we should all participate and support Takaful because by doing so, we strengthening our Muslim position in country, improving our funds to assist our Muslim brothers and sister as well."(S1).

Similarly also respondent (S2) commented:

"Why I buy Takaful? Because, you want to help others. In the concept of life product, we need one pool, if other people got accident. We need many people to contribute inside the pool. Concept of helping is a very good concept of Islam. Like "sedeqah". Because we divide some portion to put inside the pool and you can't take it back. There are three to four things can be longer you receive the rewards-pious children, alms deeds and knowledge of benefits. The concept of helping others is very good. It's a protection also."

It is noteworthy from the forgoing discussions that all the respondents unanimously agreed on the argument of relationship between buying Takaful and religion. This suggests that religion is an antecedent factor in buying Takaful. With the awareness of obligation as Muslims, Takaful is becoming an increasingly important topic of discussions contemporary literature as well as in their daily life. With encouragement and promotion by Takaful Operators with agents' efforts in selling and promoting Takaful in the modern world, Takaful Operators and most insurance companies are increasingly showing interest in acquiring Takaful's license to sell Takaful products. It is however, interesting to note that Takaful license is not limited to potential Muslim operators but also to potential non-Muslim operators as well.

\section{Conclusion and Recommendation}

This study focuses on the factors that influence the choice of Takaful over conventional insurance among Malaysians.

The study contributes new knowledge as captured by the following propositions:

i) Takaful customers have a clear concept of Takaful and the requirement of Shariah compliance. Takaful product is necessary for Muslims as replacement of conventional insurance.

ii) Takaful customers have awareness on the relationship between Takaful and religion i.e. Islam in contemporary business.

iii) The roles of Takaful agents in explaining the concept of Takaful and the benefits can be considered as aspects of worship (Ibadah). The obligation by Takaful agents in promoting the Takaful product to Muslims can be considered as acts of Dak'wah.

iv) The growth of Takaful businesses, however, remains slow compared to conventional insurance. Yet, respondents are hopeful of the growth and development of Takaful operations.

Takaful Operators and Takaful agents may use the findings of this research to justify their efforts in designing, developing and appropriate promotion and awareness interventions so that Takaful products and sales might witness extensive development in Malaysia. This could lead Malaysians in general and Malaysian Muslims in particular, to further appreciate Takaful products, which is Shariah compliant. As well, with good knowledge of Takaful operations about the justice it extents to mankind, non-Muslims in Malaysia as well as the globe may also have interest in buying Takaful products.

This study has focused on some relevant issues that represent the viewpoint of Muslim customers as well as staff of Takaful Operators. Owing to the fact that the present study employs a qualitative research approach, adopting cross-sectional research design, future researches are encouraged to empirically test the propositions put forward by this study, in order to authenticate the findings. 


\section{References}

Abduh, M., Raudhoh, M. T., \& Omar, M.A. (2012). The Performance of Insurance Industry in Malaysia: Islamic vis-à-vis Conventional Insurance. Journal of Islamic Banking and Finance, 29 (4), 40-49.

Abdullah, S. (2012).Risk Management via Takaful from a Perspective of Maqasid of Shariah. International Congress on Interdisciplinary Business and Social Science, 535-541.

Ahmad, M. I., Masood, T., \& Khan, M. S. (2010). Problems and Prospects of Islamic Banking: a case Study of Takaful. MPRA, 1-17.

Annuar, H. A. (2004). Al-Wakalah and Customers'Preferences toward It: A Case Study of Two Takaful Companies in Malaysia. The American Journal of Islamic Social Sciences, 28-49.

Arifin, J., Yazid, A. S., \&Sulong, Z. (2013).A conceptual model of literature review for family Takaful (Islamic Life Insurance) demand in Malaysia. International Business Research, 6(3), p210., 210.

Aris, N. A., Tapsir, R., \&Talib, M. K. A. (2012).Risk and Risk Management of Takaful Industry. Journal of Global Business and Economics, 4 (1).

Awang, I., \&Zakaria, S. (2005). The Conception and Response of Muslim Community to Takaful Schemes, A Case Study in Bagan Serai, Perak. Jurnal Fiqh, 2, 1-18.

Ayinde, L. O. (2012). Perception and Adoption of Islamic Insurance in Malaysia: An Empirical Study. World Applied Sciences Journal, 20 (3), 407-415.

Billah, M. M. (2000). Sources of Law Affecting 'Takaful' (Islamic Insurance. International Journal of Islamic Financial Services, 2 (4), 1-9.

Billah, M. M. (2002). Regulatory Framework of Family Takaful in the Contemporary Economic Reality. International Journal of Islamic Financial Services, 3 (3), 1-19.

Billah, M. M. (2002). Takaful (Islamic Insurance) Premium: A Suggested Regulatory Framework. Journal of Islamic Banking and Finance, 19 (3), 52-64 .

Fisher, O. C., Taylor, D. (2000). Prospects for the Evolution of Takaful in the 21st Century. Proceedings of the Fifth Harvard University Forum on Islamic Finance: Islamic Finance: Dynamics and Development Cambridge, pp. 237-254 .

Ghazali, P. L., Mohd, I., Mamat, M., \& Ahmad, W. M. A. W. (2011).Mathematical Modelling in Family Takaful. Applied Science, 3381-3388.

Gustina, \& Abdullah, N. I. (2012). Analysis of Demand for Family Takaful and Life Insurance: A Comparative Study in Malaysia. Journal of Islamic Economics, Banking and Finance, 67-86.

Hamid, M. A., \& Rahman, N. M. N. A. (2011). Commitment and Performance: A Case of Takaful (Islamic Insurance) Representatives in Malaysia. Australian Journal of Basic and Applied Sciences, 5 (10), 777-785.

Hamid, M. A., Osman, J., \&Nordin, B. A. A. (2009).Determinants of Corporate Demand for Islamic Insurance in Malaysia. International Journal of Economics and Management, 3 (2), 278-296.

Hamid, M. A., Rahman, N. M. A., Ya’amob, N. I., \&Yakob, R. (2010). Performance Determination Model of Human Capital Development for Takaful Industry in Malaysia. The Journal of Knowledge Economy \& Knowledge Management, V FALL .

Htay, S. N. N., \&Zaharin, H. R. (2011).Critical analysis on the choice of Takaful (Islamic insurance) operating models in Malaysia.Global Economics, Finance and Management Conference, 9-10 June 2011, Intercontinental Toronto Centre, Toronto, Canada.(Unpublished), (hlm. 1-17). Toronto.

Hussain, M. M., \& Pasha, A. T. (2011). Conceptual and Operational Differences between General Takaful and Conventional Insurance . Australian Journal of Business and Management Research, 1 (8), 23 28.

Ismail, N., Alhabshi, S. O., \&Bacha, O. (2011). Organizational form and efficiency: the coexistence of family takaful and life insurance in malaysia. Journal of Global Business and Economics, 3 (1), 122-137.

Kadir, M. R. A. (2011). Our Strategy towards Developing a Progressive Takaful Industry, keynote speaker at the official launch of AIA AFG Takaful Bhd, Kuala Lumpur, 28 January 2011.Retrieved from http://www.bnm.gov.my/index.php?ch=9\&pg=15\&ac=395, 25 February 2011.

Kasim, N. A. A. (2012). Disclosure of Shariah compliance by Malaysian takaful companies. Journal of Islamic Accounting and Business Research, 3 (1), 20-38. 
Lambak, S. (2013).ShariahJuristical Effect of Gharar in Predetermining Takaful Contribution. International Journal of Education and Research, Vol. 1 (2), 1-12.

Masud, H. (2011). Takaful: An Innovative Approach to Insurance and Islamic Finance. U. Pa. J. Int' ${ }^{\text {ec }}$ L., 32 (4), 1131-1164.

Matsawali, M. S., Abdullah, M. F., Ping, Y. C., Abidin, S. Y., Zaini, M. M., \& Ali, H. M. (2012). A Study on Takaful and Conventional Insurance Preferences: The Case of Brunei. International Journal of Business and Social Science, 3 (22), 163-176.

Noor, A. M., \& Abdullah, M. A. (2009).Takaful (Islamic Insurance) Benefit: Ownership and Distribution Issues in Malaysia. Journal of Islamic Economics, Banking and Finance, 5 (3), 35-48.

Qureshi, A. A. (2011). Analyzing the Sharia'ah Compliant Issues Currently Faced by Islamic Insurance. Interdisciplinary Journal of Contemporary Research in Business, 3(5), 279-295.

Rahim, F., \& Amin, H. (2011). Determinants of Islamic Insurance Acceptance: An Empirical Analysis. International Journal of Business and Society, 12 (2), 37 - 54.

Rahman, A. A., Ali, N. A., Seman, A. C., \& Ahmad, W. M. W. (2008). Comparative Study Between Auto Takaful and Auto Insurance Purchasing Behaviour Among Malaysian Undergraduates. Shariah Journal, 16(1), 75-88.

Rahman, Z. A. (2009). Takaful: Potential Demand and Growth. J.KAU: Islamic Econ., 22 (1), 53-70.

Rahman, Z. A., \&Daud, N. M. (2010).Adverse Selection and Its Consequences on Medical and Health Insurance and Takaful in Malaysia. Humanomics, 26 (4), 264-283.

Razak, M. I. M., Yusof, R. I. M. M., \& Ali, W. E. J. M. (2013).Acceptance Determinants towards Takaful Products in Malaysia. International Journal of Humanities and Social Science, 243-252.

Redzuan, H., Rahman, Z. A., \&Aidid, S. S. S. H. (2009). Economic Determinants of Family Takaful Consumption: Evidence From Malaysia. International Review of Business Research Papers, 5 (5), 193-211.

Saad, N. M. (2012). An Analysis on the Efficiency of Takaful and Insurance Companies in Malaysia: A non-Parametric Approach. ev. Integr. Bus. Econ. Res., 1 (1), 33-56.

Salleh, F., \&Kamaruddin, A. R. (2011).The Effects of Personality Factors on Sales Performance of Takaful (Islamic Insurance) Agents in Malaysia. International Journal of Business and Social Science, Vol. 2 (No. 5), 259-265.

Salleh, M. C. M., Abdullah, N. I., Razali, S. S., \& Wok, S. (2012). Takaful Agents' Roles in Accordance with the Quran and Sunnah. GJAT, 2 (2), 41-45.

Salleh, M. C. M., Abdullah, N. I, and Razali, S.S. (2013). Measuring Takaful Agent's Understanding towards the Objective and Concepts of Takaful. Journal of Islamic Finance, 2 (1), 20-30.

Schatzman, L., \& Strauss, A. L. (1973). Field Research: Strategies for a natural sociology, Englewood Cliffs, N.J.: Prentice-Hall.

Sekaran, U. (2003). Research methods for business, 4th ed. John Wiley \& Sons, Inc.: USA.

Sherif, M., \&Shaairi, N. A. (2013).Determinants of demand on family Takaful in Malaysia. Journal of Islamic Accounting and Business Research, 4 (1), 26-50.

Siala, H. (2012). Religious influences on consumers' high-involvement purchasing decisions. Emerald Group Publishing Limited [ISSN 0887-6045] [DOI 10.1108/JSM-02-2012-0046], 579-589.

Swartz, N. P., \&Coetzer, P. (2010). Takaful: An Islamic insurance instrument. Journal of Development and Agricultural Economics, 2 (10), 333-339.

Yakob, R., Yusop, Z., Radam, A., \& Ismail, N. (2012).Camel Rating Approach to Assess the Insurance Operators Financial Strength. Jurnal Ekonomi Malaysia, 46 (2), 3-15.

Yazid, A. S., Hussin, J. A. M. R., \&Daud, W. N. W. (2012). Determinants of Family Takaful (Islamic Life Insurance) Demand: A Conceptual Framework for a Malaysian Study. International Journal of Business and Management, 7 (6), 115-127.

Zainuddin, S., \& Noh, I. N. M. (2013). An overview of the emergence of Takaful: An Islamic type of insurance policy. International Journal of Business and Economics Research, 2 (5), 112-115. 